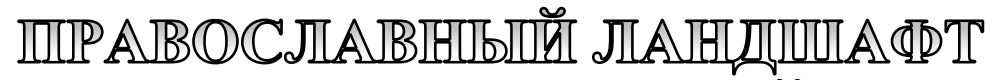

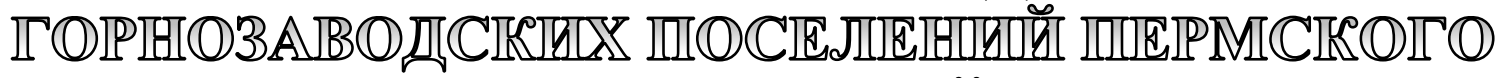

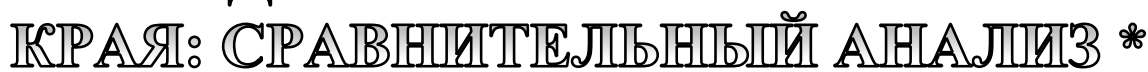

\author{
А.В. Вострокнутов, Пермский государственный национальный исследовательский университет
}

\section{Для цитирования:}

Вострокнутов А.В. Православный ландшафтт Горнозаводских поселений Пермского края: сравнительный анализ // Вестник Пермского федерального исследовательского центра. - 2021. - № 4. - С. 70-81. https://doi.org/10.7242/2658-705X/2021.4.7

На основании архивных, опубликованных, полевых этнографических источников производится сравнительный анализ православного ландшафта 13 горных заводов, условно разделенных на две группы: северную и южную. Деление это обусловлено не только географически, но и особенностями исследуемого ландшафта. Для северных заводов характерно распространение сакрального пространства от храма, который является центром, по всему заводу и далее к его рудникам. Это выражается в православных названиях улиц и частей заводского поселка. Помимо горизонтального распространения, присутствует вертикальное - православные названия получают рудные пласты на некоторых рудниках. Южные заводы, напротив, используют базовую модель сакрального пространства, функционирующего вокруг храма. Кроме этого были выделены три модели месторасположения храмов: центральная, периферийная с высотной доминантой и периферийная при въезде в завод. Все это позволило охарактеризовать православные ландшафты разных заводов, выделив сходные и отличительные черты.

Ключевые слова: православие, иерковь, храм, завод, поселок, пространство, культурный ландшафт, православный ландшафт, сакральное пространство.

Урал в истории и культуре России прочно ассоциируется с активным развитием промышленности начиная с XVIII в. Ее становление было тесно связано с формированием сети заводов и заводских поселений, появлением особой категории заводского населения - мастеровых - основных рабочих уральских заводов.

Промышленные предприятия, появившиеся на Урале еще в XVII в., стали на- зываться горными заводами ввиду особенностей своего расположения, обусловленного спецификой технологического производства - зависимостью от воды.

Д.Н. Мамин-Сибиряк в одном из своих очерков отмечал, что все горные заводы похожи между собой [19, с. 354]. Действительно, если посмотреть на горный завод с точки зрения его функционирования как промышленного предприятия, то сходство на лицо.

\footnotetext{
* Исследование выполнено за счет гранта Российского научного фонда (проект №20-18-00269
} «Горная промышленность и раннезаводская культура в языке, народной письменности и фольклоре»). 
Наиболее подходящей местностью для обустройства заводского пруда являлась долина небольшой реки, имеющей крутые берега. Здесь она перегораживалась плотиной, в результате чего образовывался пруд. Под плотиной возводились заводские цеха, которые использовали силу падающей на водобойные колеса воды для приведения в действие своих механизмов. Выше завода располагались заводская контора, дома рабочих и храм. Следует отметить правильную планировку заводских поселков по сравнению с сёлами и деревнями.

Сырьё для производства добывалось на рудниках, находившихся в окрестностях завода. При истощении их организовывалась доставка сырья с других заводов, иногда значительно удаленных друг от друга. Так, например, Добрянский завод Строгановых перерабатывал чугун, полученный на Кувинском и Билимбаевском заводах тех же владельцев, сплавляемый по Чусовой и Каме и доставляемый гужом. Протяженность сплава составляла более 600 км.

Для выплавки металла использовался древесный уголь, выжиганием которого занимались крестьяне окрестных селений или подзаводские рабочие, занятые на вспомогательных производствах, если таковые имелись вблизи завода [8, с. 4]. В заводских дачах также располагались сенокосные угодья, где мастеровые заготавливали корм для скота.

Несмотря на перечисленные схожие элементы в устроении горного завода, каждый из заводских поселков, как и любое другое поселение, имел свои отличия, в т.ч. и в организации пространства посёлка и завода. В этой связи, на наш взгляд, интересно будет найти отличия между этими заводскими поселениями. Поэтому стоит заглянуть в организацию культурного пространства (пространства, которое формировалось и осмыслялось населением) заводского поселка, а именно, применительно к теме данной работы, в его сакральную часть.
Под сакральным пространством мы понимаем, вслед за рядом авторов, значимые точки пространства, места концентрации положительной (в нашем случае) и отрицательной информации [16, с. 80]. Для горнозаводского населения сакральное пространство - это, в большинстве своем, православный ландшафт.

В данной работе проводится анализ православного ландшафта заводских поселений при Добрянском, АрхангелоПашийском, Кусье-Александровском, Бисерском, Лысьвенском, Очёрском, Нытвенском, Юго-Камском, Юговском, Курашимском, Бизярском, Анинском и Ашапском горных заводах. Территориально данные заводы располагались в бывших Соликамском, Оханском, Пермском, Кунгурском и Осинском уездах Пермской губернии. Ныне это Добрянский, Ильинский, Очёрский, Нытвенский, Горнозаводской, Лысьвинский, Пермский и Осинский районы современного Пермского края. Данные предприятия были как железоделательными, так и медеплавильными.

В данной работе мы используем в качестве источников архивные документы, хранящиеся в Государственном архиве Пермского края, Горнозаводском краеведческом музее им. М.П. Старостина, Лысьвенском краеведческом музее, a также публикации XIX-XXI вв. Отельным источником являются этнографические данные, полученные в ходе полевой работы в 2020-2021 гг., представленные записями опросов информаторов и личными наблюдениями автора.

Мы уже перечислили пять ключевых точек заводского пространства. Это плотина, пруд, заводские корпуса, заводская контора и храм. Следует отметить, что горнозаводские поселки являлись самодостаточными в религиозном плане, в противовес сельской округе, где сельский храм являлся приходским для окрестных деревень: в каждом заводе был храм, который, чаще всего, являлся приходским только для жителей самого завода. 
Прежде рассмотрения непосредственно православного пространства указанных заводских посёлков и его анализа, кратко охарактеризуем каждый из горных заводов, вошедших в исследование.

\section{Краткая история исследуемых заводов}

Добрянский завод был основан в 1752 г. и введен в эксплуатацию в 1754 г. Предприятие специализировалось на выплавке меди, а после истощения медных месторождений - железа [25, с. 456-457]. В 1825 г. в помощь первому заводу ниже по течению p. Добрянки начинается строительство второго - Софийского $[15$, с. 10]. Заводы стали называть «Верхний» и «Нижний», соответственно. В связи с наполнением Камского водохранилища в 1956 г. завод был закрыт, его оборудование и производственные помещения демонтированы [21, с. 183-186].

Архангело-Пашийский железоделательный завод был основан в 1786 г. князем М.М. Голицыным. Завод получил двойное название в честь небесного покровителя его основателя - Архистратига Михаила. В 1879 г. С.М. Голицын, владелец завода на тот момент, сдал его в аренду Франко-русскому Уральскому обществу, а затем, в 1889 г., - Камскому акционерному обществу железо-сталелитейных заводов. Однако все мероприятия по модернизации производства не приносили должных плодов. В 1917 г. завод был национализирован и стал называться Пашийским заводом [21, с. 36-37]. Ныне на месте данного предприятия функционирует Пашийский металлургическо-цементный завод.

Кусье-Александровский железоделательный завод был основан в 1751 г. бароном Александром Григорьевичем Строгановым. После его смерти завод был разделен между его дочерьми А.А. Голициной и В.А. Шаховской [24, с. 379], данное разделение продолжалось практически до конца $\mathrm{XIX}$ в. Завод получил свое название по имени первого названия и реки Кусья. Производство на заводе прекратилось в 1918 г. После окончания Гражданской войны он был закрыт [21, с. 283].
Бисерский железоделательный завод был основан в 1786 г. княгиней В.А. Шаховской $[17$, с. 316$]$. Этот завод является самым восточным из исследуемых нами в данной работе. Название завод получил по реке Бисер, при впадении которой в Койву он и был основан. Последним единоличным владельцем завода был граф П.П. Шувалов. После его смерти завод перешел в управление «Паевого товарищества наследников П.П. Шувалова», а затем акционерного общества «Лысьвенский горный округ наследников графа П.П. Шувалова». Закрыт завод был в 1926 г. [21, с. 74]. Следует отметить, что его заводские строения сохранились до сих пор.

Лысьвенский железоделательный завод был основан В.А. Шаховской в 1785 г. и пущен в строй в 1787 г. [21, с. 300-304]. Название завод получил по р. Лысьве, на которой и был основан завод. Следует отметить, что это один из немногих горных заводов, который сохранился до сих пор (разумеется, претерпевая в разное время модернизацию) как Лысьвенский металлургический завод.

Нытвенский завод был основан баронессой М.А. Строгановой как медеплавильный и железоделательный в 1756 г., а пущен в строй в 1760 г. Название получил по р. Нытве (правому притоку p. Камы). Очень скоро, в связи с истощением медных руд, завод полностью сконцентрировался на производстве железа, работая на чугуне, поставляемом с Архангело-Пашийского и Кусье-Александровского заводов. За время своего существования Нытвенский завод претерпевал изменения, перепрофилировался в производстве [21, с. 362-363]. На сегодняшний день Нытвенский завод остается градообразующим предприятием, выпуская различную продукцию.

Очерский железоделательный завод был основан на одноименной реке графом А.С. Строгановым в 1759 г., а пущен в строй в 1761 г. Чугун для переплавки доставлялся сюда сплавом по Чусовой и Каме с Билимбаевского завода Строгановых. За годы существования завод всегда 
оставался в собственности Строгановых. B конце XIX в. на предприятии наступил кризис, вызванный разными причинами: высокой себестоимостью производимого железа, низким его качеством и т.д. Вследствие этого в 1911 г. Очерский завод был закрыт [21, с. 373-374]. Ныне на месте горного завода располагается АО «Очерский машиностроительный завод».

Юго-Камский медеплавильный и железоделательный завод был основан бароном А.Г. Строгановым в 1746 г. Название свое получил по реке, на которой был устроен заводской пруд. После смерти А.Г. Строганова, заводом владела его дочь, В.А. Шаховская, после он перешел во владение ее внучки княгини Варвары Петровны Шуваловой-Полье-Бутеро-Родали, позже - ее сыну А.П. Шувалову [21, с. 525]. Завод как металлургическое предприятие действовал до недавнего времени.

Юговской казенный медеплавильный завод был основан в 1735 г., пущен в строй в 1736 г., а в 1740 г. в помощь ему был построен еще один, немногим выше по течению р. Юг, по которой и получил название этот завод. В 1757 г. эти заводы были переданы в частное владение графу И.Г. Чернышеву, который, однако, в 1770 г. продал их обратно казне. Вновь заводы попали в аренду только в 1892 г. Однако арендаторы, ни Д.И. Захаровский (и его наследники), ни И.Н. Урбанович не смогли восстановить падающее производство и вывести заводы из кризиса, вследствие чего они были закрыты в 1909 г. [21, с. $524-525 ; 24$, с. 135$]$.

Аннинский горный завод был основан И.Г. Чернышевым в 1758 г. на р. Бабка, отчего второе название за заводом закрепилось как «Бабкинский». Пущен в работу завод был в 1760 г., а в 1770 г. продан казне. Короткое время (с 1788 по 1798 гг.) здесь располагался Аннинский монетный двор. Окончательно завод был закрыт в 1806 г. [21, с. 32-33].

Курашимский медеплавильный завод был основан Г.П. Осокиным в 1739 г. Пущен в 1742 г. Завод располагался на р. Курашим, правом притоке р. Бабки. По названию р. Курашим завод и получил свое название. В 1804 г. завод был продан А.А. Кнауфу, а в 1828 г. перешел в казенное управление. Позже восстановить производство пытались, переведя завод под управление акционерной компании Кнауфских горных заводов. Однако в 1862 г. Курашимский завод был закрыт [21, с. 281]. Поселение получило статус села, сохраняющийся до сих пор.

Бизярский завод был основан П.И. Осокиным на р. Бизярке (давшей название заводу, правый приток р. Бабки) в 1740 г., а первая медь была получена в 1741 г. В 1804 г. И.П. Осокин, наследник предыдущего владельца, продал завод А.А. Кнауфу. Позже, в 1828 г., из-за финансовых проблем Бизярский завод был взят под казенное управление. Окончательно закрыт в 1863 г. [21, с. 69-70].

Ашапский медеплавильный (позже также железоделательный) завод был основан А.Н. Демидовым в 1741 г., запущен в 1744 г. В 1770-е на заводе было начато железелательное производство - чугун для этого поставлялся с Уткинского завода тех же владельцев. В 1848 г. Ашапский завод, испытывавший финансовые трудности, был передан в управление «Товариществу Суксунских горных заводов», а затем, в 1863 г., - в казенное управление. После пожара 1869 г. завод не восстанавливался и как металлургическое предприятие перестал существовать [21, с. 41-42].

Все заводы, рассматриваемые в данной работе, были пущены в строй в середине - второй половине XVIII в. География их расположения обширна - от предгорий Среднего Урала и тайги на севере до лесостепи на юге. Далее мы продолжим выделять северные заводы (Добрянский, Архангело-Пашийский, Бисерский, Кусье-Александровский, Нытвенский, Лысьвенский и Очерский) и южные (Юговской, Юго-Камский, Курашимский, Аннинский, Бизярский, Ашапский). Деление это, как будет показано ниже, обусловлено теми чертами православного ландшафта, которые отделяют данные группы заводов друг от друга. 
Посвящение и месторасположение храмов в горных заводах

Как мы уже отмечали, храм, наряду с прудом, плотиной и заводскими постройками был одной и ключевых точек горнозаводского культурного ландшафта. Для сакрального пространства поселка он был, безусловно, центром, доминантой. В этой связи интересно проследить не только особенности посвящения храмовых престолов, но и месторасположения самого храма относительно плотины, реки и заводских построек.

Добрянский завод. Первый деревянный храм в Добрянке был построен в 1769 г. В этом году был освящен Никольский престол. Его дополнил в 1778 г. престол в честь Рождества Богородицы. Данный храм сгорел в пожаре 1831 г. [14, с. 297]. На его месте началось сооружение новой каменной церкви, которое затянулось - главный придел в честь Рождества Богородицы освятили только в 1852 г. [15, с. 14]. В память об освобождении крестьян на средства мастеровых были возведены и в 1868 г. освящены еще 2 придела - в честь Николая Чудотворца и св. благоверного князя Александра Невского [6, с. 65]. Рождество-Богородичный храм располагается на правом берегу заводского пруда сразу же по окончанию плотины. За ним, выше по склону горы, разместились дома мастеровых. Ниже под плотиной - заводские корпуса, напротив - здание заводской конторы.

В связи со своим расположением, храм является доминантой не только сакрального пространства, но и всего культурного ландшафта завода: рабочий, следуя по заводскому свистку на смену и обратно, непременно проходил мимо церкви.

В связи с длительной постройкой главного заводского храма после пожара Софья Владимировна Строганова, владелица завода, спонсировала строительство деревянной церкви при кладбище, освященной в честь прославленного незадолго до этого святителя Митрофана Воронежского в 1837 г. [14, с. 297].
Оба храма находились в прямой видимости друг друга. В настоящее время оба они сохранились.

Архангело-Пашийский завод. Свято-Троицкий храм при заводе был построен в 1791 г. Помимо главного Троицкого придела, здесь имелись еще два: Богоявления и Архангела Михаила. Следует отметить, что приделы Богоявления и Архангела Михаила располагались на нижнем (тёплом) этаже и были освящены значительно раньше главного Троицкого придела, который располагался на втором (холодном) этаже. Освящения состоялись, соответственно, в 1791, 1794 и только в 1827 гг. [9, с. 1].

Храм находится на правом берегу пруда, выше плотины по течению, на склоне холма, спускающегося к пруду. Это наиболее возвышенное в заводе место. Но, одновременно, храм находился не в центре завода, а на его окраине, по дороге на кладбище и дальше на рудники. Но, несмотря на окраинное положение, благодаря высоте места расположения Троицкий храм являлся доминантой (как высотной, так и сакральной) Архангело-Пашийского завода. Здание храма сохранилось до сих пор.

Кусье-Александровский завод. Современное здание храма Казанской иконы Божией Матери было построено в 1843 г., однако освящение его состоялось только в 1848 г. [20, с. 11-12].

Ранее в заводе находился Трёхсвятительский молитвенный дом, о чем свидетельствуют метрические книги, хранящиеся в фондах Государственного архива Пермского края. Самая ранняя из них датирована 1838 г. [3]. Как и в случае с Архангело-Пашийским заводом, храм располагался на высоком правом берегу пруда, несколько выше и в стороне от заводского поселка, дома которого находились ниже по склону либо на другой стороне заводского пруда.

Бисерский завод. По сведениям Н.С. Попова, в начале XIX в. здесь уже имелась также деревянная церковь $[24$, с. 328]. Этот храм имел то же посвящение, что и построенный в 1848 г. Петропав- 
ловский храм [18, с. 326] - в Государственном архиве Пермского края хранятся метрические книги Петропавловской церкви Бисерского завода с 1800 г. [2].

Храм располагался на правом возвышенном берегу р. Бисер, несколько в стороне от основного поселка. В настоящее время этот храм не сохранился. На его месте построен новый.

Лысьвенский завод. В документах, хранящихся в Государственном архиве Пермского края, имеются метрические книги Троицкой церкви Лысьвенского завода начиная с 1800 г. По сведениям Адрес-Календаря Пермской епархии за 1909 г. деревянная Троицкая церковь была построена в 1799 г. [13, с. 65-66]. Она имела два придела: холодный - Троицкий и теплый - Николая Чудотворца. В 1891 г. началась постройка нового каменного Троицкого храма, освященного в 1899 г. [14, с. 487, 489]. В советское время Троицкий храм был разрушен. Сейчас он восстановлен на прежнем месте.

Храм располагался на правом берегу пруда, непосредственно вблизи плотины, возвышаясь над заводскими постройками, несмотря на относительно слабовыраженный рельеф, занимаемый заводским поселком.

Нытвенский завод. Первоначально деревянный Спасский храм, построенный, скорее всего, сразу после пуска завода, располагался на главной заводской площади, в ее северной части, т.е. близ плотины, но несколько в стороне. После пожара 1860 г., уничтожившего храм, под него было передано здание заводоуправления. Теперь Спасский храм занял место около плотины в южной части заводской площади. Православный ландшафт Нытвы в 1873 г. дополнила кладбищенская Всехсвятская церковь, а в конце XIX в. - храм Александра Невского [14, с. 428-429].

Очерский завод. Первая деревянная церковь в Очерском заводе упоминается в 1772 г. в записках Иоганна Питера Фалька. Она имела два придела: Архангела Михаила и Николая Чудотворца. Храм этот сгорел в 1808 г., вместо него при кладбище в 1812 г. был возведен Александро-Невский храм (не сохранился) [23, с. 84, 87]. Каменная Архангельская церковь (с теми же приделами, что и у деревянной) была отстроена в 1841 г. [14, с. 366-368].

Храм располагается на левом берегу p. Очер, вблизи плотины, немногим ниже ее по течению, над заводскими корпусами, служа одной из высотных доминант поселка.

Курашимский завод. В Курашимском заводе деревянный храм Иоанна Предтечи был построен в 1765 г. Престолов в нем было два: Пророка, Предтечи и Крестителя Господня Иоанна и великомученицы Екатерины $[13$, c. 61], что обусловливало престольные праздники заводского поселка, а потом и села. Место расположения православного храма удалено от реки Курашимки на 0,2 км. Храм, как и заводской поселок, находится на правом ее берегу. Местность ниже заводской плотины ровная, без резких перепадов высот. Церковь находилась при въезде в поселок.

Интересно отметить, что храм не являлся ни высотной доминантой, как, например, в Юговском, Юго-Кнауфском, Архангело-Пашийском заводах, ни центральным местом завода, как в случае с расположенными у плотин храмами в Добрянке, Ашапе, Билимбае, Очере, Юго-Камске. Однако центральную роль он играл несколько в ином плане.

Иоанно-Предтеченский храм имел большое значение для прибывающих и убывающих путников - он был по сути своей благословением при въезде и «на дорогу». В этом плане такое храмовое расположение роднит православный ландшафт Курашимского завода с соседним Бизярским, принадлежавшим также Осокиным.

Аннинский завод. Адрес-календарь Пермской епархии за 1909 г. указывает в заводском селении деревянный храм Успения праведной Анны, построенный в 1848 г. [13, с. 130]. В фондах ГАПК имеются метрические книги Аннинской церкви за 1776 г. [4]. Мы можем предпо- 
лагать, что храм был построен в ближайшее после пуска завода время, т.е. в 60-е годы XVIII в., в настоящее время от храма сохранился лишь фундамент, здесь же поставлен крест.

Храм располагался около кладбища на высоком левом берегу р. Бабки, на значительном удалении от нее (0,5 км). Судя по правильной планировке сохранившихся домов на этом берегу, заводской поселок и сам завод располагались под храмом. Таким образом, Аннинская церковь служила высотной доминантой для данной местности.

Бизярский завод. Адрес-календарь Пермской епархии за 1909 г. указывает здесь только один храм, Сретения Господня, построенный в 1843 г. [13, с. 137]. В фондах Государственного архива Пермского края хранятся метрические книги Христорождественской церкви Бизярского завода начиная с 1782 г. [5]. Метрические книги данного храма прослеживаются до 1842 г. [1]. Жители сохраняют память о двух храмах в заводском поселке до сих пор. Также проясняется, почему в небольшом заводе имеется 2 храма - Сретенский был построен после пожара, уничтожившего Христорождественский:

«[Церковь в Бизяре была?] - Была, была иерковь, две было иеркви в Бизяре, да. Одна закрыта в Советское время, (другая) сгорела. А, вот Христорождественская иерковь, Пермский район, село Бизяр и Сретенская церковь, значит. Одна закрыта, (которая) освящена в тысяча восемьсот сорок третьем году, а вот эта вторая, она сгорела, там на месте этой церкви сейчас крест поставили» (пос. Октябрьский, Пермский район, 2020).

Таким образом, мы можем заключить, что изначально, скорее всего, сразу после пуска завода, при нем был построен Христорождественский храм, который сгорел, очевидно, в 1842 г., после чего новый храм был освящен в честь Сретения Господня. На сегодня место, где находился Христорождественский храм, отмечено крестом. Возможно, там же располагался Сретенский храм.
Храм находился на левом берегу р. Бизярки, на достаточном он нее удалении (около 0,5 км), ниже заводской плотины. Местность (левый берег Бизярки), где был расположен храм, да и весь завод, достаточно ровная, без высотных доминант (в отличие от правого берега Бизярки, где находится Тёплая гора с рудниками). Храм в данном случае находился на въезде в заводской посёлок, возможно, на момент функционирования завода, это была именно окраина. Таким образом, храм, несмотря на то что он не выделялся как высотная доминанта (как это можно наблюдать, скажем, в Архангело-Пашийском заводе), тем не менее осуществлял свою функцию центра сакрального пространства завода, именно встречая прибывающих сюда. Отметим, что за Бизяром не было уже больше селений, соответственно храм не только встречал приезжающих, но и провожал их, поскольку следовать дальше они не могли.

Юговской завод. Кирпичный Христорождественский собор, построенный в 1811 г., имел три престола: Рождества Христова, мучеников Флора и Лавра и Николая Чудотворца. К собору приписан храм Ильи Пророка на кладбище [13, с. 57]. Изначально храм был деревянный. Память об этом до сих сохраняется у местных жителей:

«...Христорождественский собор, он там сначала был деревянный тоже в тышу семьсот котором-то году, ему уш было лет сто этому деревянному, он тоже обветшил, в общем и решили мы в тысячу восемьсот одиннадиатом вот этот построили кирпичный, он трёх престольный...» (пос. Юг, Пермский район, 2020).

Оба храма находятся на высоких коренных берегах р. Юг. Христорождественский храм - на ее левом берегу, над заводским прудом, Пророко-Ильинский на правом берегу, на значительном удалении (0,5 км) от реки. Христорождественский храм расположен в той части современного Юга, где начали селиться первые его рабочие. Таким образом, храм уже тогда являлся для них центром, сам поселок 
вообще располагался несколько обособлено от заводских корпусов (в 0,3 км), что вызывает интерес, поскольку чаще всего заводские поселки примыкают непосредственно к самому заводу, являясь его составной нераздельной частью. Следует отметить, что при разрастании заводского поселка Христорождественский собор остался не только духовной, но и высотной доминантой как для левого берега пруда, так и для правого.

Ильинский храм кладбищенский и расположен в противоположном конце заводского поселка, при въезде. Оба храма видны с тех мест, где они стоят.

Юго-Камский завод. Каменный Свято-Троицкий храм построен в 1834 г. [13, с. 59]. Храм имел три престола. Наименования их до сих пор сохраняются в памяти населения:

«Ну, а храм Святой Троицы, тут было три алтаря. Вот центральный алтарь здесь был во имя Христа Спасителя. Там, значит, был слева, во имя Божьей Матери, а справа - Николай Чудотвориа. И вот первый-то алтарь когда был освящеен, то есть освящение храма состоялось в тысяча восемьсот тридиать четвертом году, но потом еще в течение семидесяти лет он достраивался. И последнюю вот, Николаю Чудотвориу был освящен в тысяча девятьсот седьмом году» (пос. Юго-Камский, Пермский район).

Следует отметить, что в ГАПК хранятся метрические книги Свято-Троицкой церкви начиная с 1784 г. [7]. Следовательно, храм был построен, очевидно, в ближайшее после пуска завода время, а в 1834 г. уже был отстроен в камне.

Храм расположен на левом берегу заводского пруда, у плотины. Такое месторасположение делает его заводским центром, несмотря на близость непосредственно к самому заводу, располагавшемуся ниже. Таким образом, Свято-Троицкий храм является высотной доминантой для жителей заводского поселка, несмотря на ровность местности, без значительных перепадов высот.
Ашапский завод. Каменный Свято-Троицкий храм, построенный в 1829 г. [13, с. 134], имел, помимо главного, Троицкого, престола еще два: Петра и Павла и Рождества Богородицы.

Храм расположен на правом берегу заводского пруда, немного южнее плотины, на надпойменной террасе. Улица, проходящая по плотине, соединяет ее с храмом.

Подводя итоги анализа храмов в горнозаводских поселках, мы можем выделить три модели их месторасположения.

1-я модель: Центральное местоположение в пространстве: храм-пруд-плотина (Добрянка, Ашап, Нытва, Лысьва, Юго-Камский, Очер). Данная модель наиболее часто встречается на горных заводах. Помимо включенных нами в данную работу, эту модель можно встретить, например, в Билимбае, Каменке, Нижнем Тагиле, Невьянске, Кушве и т.д. Популярность данного расположения не удивительна - храм, как мы уже говорили, был одной из пяти ключевых точек заводского пространства, и в данном случае расположение его близ плотины и пруда, а следовательно, и около конторы и заводских корпусов, делало пространство завода завершенным.

2-я модель: храм на периферии заводского поселка - при въезде (Курашим, Бизяр). Храм, не занимая центрального положения в пространстве заводского поселка, тем не менее, имел большое значение для прибывающих и убывающих путников - он был по сути своей благословением при въезде и «на дорогу. Таким образом, несмотря на периферийное месторасположение, храм остается одной из значимых точек пространства.

3-я модель: периферийное положение с высотной доминантой (Архангело-Пашийский, Кусье-Александровский, Бисерский, Аннинский и Юговской заводы). В данной модели храмы располагаются на окраине заводских поселков, не при въезде, но воспринимаются как одни из доминант заводского пространства, благодаря своему главенствующему в высотном плане местоположению. Таким образом, они отсто- 
ят от центра заводского пространства: плотины, пруда и т.д., но занимают свою «нишу» в высотном плане, служа своеобразным ориентиром, подобно сельским храмам, стоящим по берегам рек.

\section{Православные топонимы в планировке поселка}

Важную роль в формировании православного ландшафта заводских поселений играли улицы, носящие православные названия. Следует отметить, что не на всех исследуемых заводах такие улицы имелись. Тем не менее обратимся к фактам.

На Добрянском заводе храмы (Никольский придел Рождество-Богородицкого храма и Митрофаньевский) дали название 1 и 2 Никольским и 1-7 Митрофаньевским улицам. Помимо этого имелась Троицкая улица, Покровская улица и Покровский переулок [15, с. 66].

В Архангело-Пашийском заводе имелись Богоявленская, Никольская, Архангельская, Троицкая, Прокопьевская, Преображенская, Петропавловская улицы.

На Нытвенском заводе, судя по его плану, находящемуся в Нытвенском краеведческом музее, были Михайловская, Спасская, Никольская, Ивановская, Малая Ивановская, Сергиевская, Вознесенская улицы.

В 1813 г. в Очерском заводе был разработан единый план заводского селения с 13 улицами, которые шли вдоль заводского пруда, кроме ул. Торговой, шедшей от плотины в обе стороны поселка. Шесть из них носили православные названия: Павловская, Михайловская, Благовещенская, Никольская, Вознесенская, Архангельская [23, с. 71].

Как отмечает И.И. Спехов, пространство заводского поселка Лысьвенского завода был разделен на четыре зоны, каждая из которых имела свой престольный праздник: Успение (15 августа), Богородицын день (Рождество Пресвятой Богородицы 8 сентября), Иванов день (преставление апостола и евангелиста Иоанна Богослова 26 сентября) и Покров (1 октября). Во время праздненств духовенство обходило «поголовно жителей» указанных частей поселка [12, с. 112-113].

На других заводах, речь о которых идет в данной статье, либо нет информации о названиях улиц, либо информаторы напрямую говорят об отсутствии православных названий:

«[Улицы как назывались?] - А вот улищы тоже не знаю как назывались, были дома, были, щасничё нет всё и людей нет» (Аннинск, 2020);

«Ой Если я вот штоо сльшала от мамы, это вообще называния были стращные, там э Нагорные территория, там значит Заферма была, за фермой, там была Вшивая горка, там ещё какая-то, извините, Засраная улица была вот ну вот такие вот, ну просто они так называли, может быть то, ито грязная какая-то улииа, а в целом сейчас у нас там э улииа Революиионная» (пос. Октябрьский, Пермский район, 2020. О Бизяре);

«[А вот еще, как в Юго-Камске улищь назывались? Вот раньше, до револючии.] - До револючии они не назывались. - [Вообще никак?] - Да. «Где живешь?» - [А сами-то как-то различали?] - Только вот у нас значит, был Казанский тракт и одне улииу у нас в народе называли КетОвская. Она шла на кладбище. И вот до сих пор вот так» (Юго-Камский, 2020);

«... И оно (заводское поселение) начиналось с той улииы, ее звали Больша улииа. Теперь она улииа Карла Маркса. Вся эта постройка была - Деревенька. И как раз Большая улища. И тут потом построили. И у кажой улищыл, я даже помню, какое было название. Сива была. Наша Набережная, это была Нижняя улииа. А это как бы Река. После Ленина улииа идет Первомайская, а была Новенька Слободка. А проулок с Сивой и Новенькой Слободку назывался Тараканка. А та Советская улица называлась Зарошша. Так вот дедушка мне и рассказывал. Говорит, когда строились, тут мы проходили, был лес заросший, так и назвали Заросшша» (Курашим, 2008); 
"[Как до револючии улицьы назывались] не знаю, я и говорю Заячий порядок, да Анинская, да э этот [почему Анинская] Анинская там село, Гавриловская, Гаврилово э там, где-то тоже есть [улица Гавриловская] ну так э Гавриловская, да. Так современные названия э Ленина, Карла Марта тэ, тэ, тэ, тэ, Пихто́вая - это Большая вот, Анинская вот - Карла Маркса Анинская и Свободь [она до револючии была Анинская] да, Малая Слутка, ну это вот тут она как на горе, Маленькая улочка. Вот Бизярская э сейчас она э Горькова, Бизяр есть такое село или што ли вот. Рыю, Рыжевска́я это, Юговская, Некрасова, Купурка...» (Юг, 2020).

Последний пример (бывший завод Юг) показывает нам, что названия Аннинская и Гавриловская улицы были даны не в честь православных святых, а в честь соседних поселений.

Таким образом, мы можем заключить, что на юге исследуемой территории, в отличие от севера, отсутствовали православные наименования улиц. Возможно также, что отсутствие православных названий в планировке заводских поселений может указывать на то, что данная местность (где располагались заводы) уже была освоена достаточно долго в сельско-хозяйственном плане [24, с. $137 ; 21$, с. $69,281,524]$.

Этим же можно объяснить практически полное отсутствие православных названий рудников в южных заводах. Нам удалось найти лишь три наименования рудников Юговского завода, которые можно отнести к православным - это Павлоивановский (Ивано-Павловский), СвятоНикольский и Васильевский рудники, остальные имеют другие названия (например, Юмыш, Татарский, Бершетский, Чекабеевский) [24, с. 136; 22, с. 480].

Мы можем заключить, что мастеровые, очевидно, использовали в топонимике уже сложившиеся названия, кроме этого местные татары и башкиры зачастую сами выступали в качестве рудознатцев и, разумеется, давали названия рудникам, основываясь на своем мировоззрении.
Северные заводы, напротив, имели многочисленные рудники с православными названиями. Вокруг Архангело-Пашийского завода располагались рудники, имевшие такие названия, как Тихвинский, Богородский, Никольский $[10 ; 11$, c. 5]. Кусье-Александровский завод работал на руде, в т.ч. доставляемой из Троицкого, Исаковского, Богородского, Семеновского, Долматовского рудников.

На этом же заводе православный ландшафт распространялся вглубь земли: пласты руды также получали свои названия, среди которых встречаются и православные. На Куртымском руднике имелись Покровский, Введенский и Павловский пласты руды. Отдельные части рудников также получали названия. На Богородском руднике имелись Богородская шахта и Екатерининский шурф [26, с. 57-65].

Бисерский завод обслуживали рудники, имевшие следующие православные названия: Ильинский, Семеновский, Горевознесенский, Елисеевский, Прокопьевский, Петровский, Никольский, Покровский, Андреевский, Старо- и НовоВоскресенский, Васильевский, Ивановский, Петропавловский, Троицкий. Кроме этого, существовали золотые рудники: Крестовоздвиженский, Петровский, Никольский, Георгиевский, Ивановский, Андреевский. Если говорить о количественном соотношении названий, то, например, в даче Бисерского завода из 63 железных и золотых рудников 21 (то есть 1/3) носили православные названия [18, с. 323-324].

\section{Выводы}

Таким образом, мы можем выделить общие и отличительные черты сравниваемых заводов. К общим можно отнести наличие в каждом заводе храмов, которые разнятся по местоположению в заводе, всего было выделено три модели: от центрального у плотины (модель 1) до периферийного (модели 2 и 3). При этом, в любом случае, церковь имела большое значение для сакрального пространства завода: находясь на пе- 
риферии, она все равно была либо высотной доминантой, либо «встречающей» и «провожающей» путников. Храмы являлись центрами формирования православного пространства.

К отличиям в сакральном пространстве заводов, в первую очередь, относится концентрация православного ландшафта внутри самих заводов на юге изучаемой территории и выход его за пределы заводских поселений на севере. Речь идет о наименовании улиц, частей заводских поселений, их рудников - т.е. распространение православного ландшафта на многие километры вокруг завода и даже вглубь земли, если говорить о православных наименованиях пластов руды.

Мы можем сделать вывод, что для части заводов (на юге) православный ландшафт был достаточен в своей базовой форме - наличии храма и всех событий, связанных с ним (таинства, богослужения, праздники, крестные ходы, молебны и т.д.). Однако на севере изучаемой территории прослеживается совершенно другая картина - базовая форма православного ландшафта выходит за пределы заводского поселка, распространяясь по окрестностям и всему заводскому пространству.

На наш взгляд, причин этому несколько. В первую очередь, это особенности освоения земель. На юге они уже были освоены со сложившейся локальной топонимической системой, а на севере их приходилось, в прямом смысле, осваивать с нуля, что приводило к наполнению смыслами всего окультуренного ландшафта. Во-вторых, на формирование и развитие православного ландшафта могли иметь влияние какие-либо личные вкусы, как заводского начальства, так и самих владетелей заводов. Примером этому может служить Юговской завод, принадлежавший казне, где для наименования рудников использовались православные названия, что можно связать с общим православным государственным курсом.

Православный ландшафт на горных заводах, как было прослежено, имел в себе как базовые черты, свойственные сакральному пространству большинства поселений, так и свои специфические черты, которые проявлялись в ряде случаев.

\section{Библиографический список}

Проект Государственного архива Пермского края «Поколения Пермского края» [Электронный pecypc] - URL:http://pokolenia.permkrai.ru/.

1. ГАПК Ф.37. [Бизярский завод, Христорождественская церковь, метрическая книга] ОП. 3. Д. 6.

2. ГАПК Ф.37. [Бисерский (Бисер) завод, Петропавловская церковь, метрическая книга за 1800 г.] О. 1. Д. 11a.

3. ГАПК Ф.37. [Кусье-Александровский завод, Трёх-Святительская церковь, метрическая книга за 1838 г.] О. 1. Д. 77.

4. ГАПК Ф.37. [Метрическая книга Анно-успенской церкви Аннинского завода Кунгурского уезда Пермской провинции Казанской губернии за 1776 г.] Оп. 3. Д. 119.

5. ГАПК Ф. 37. [Бизярский (Бизяр) завод, Христо-Рождественская церковь, метрическая книга за 1782 г.] О. 1. Д. 475.

6. ГАПК. Ф. 531. [Батанов Владимир Михайлович. История Добрянского завода (1752 - 1916). Гл. IV. Первые десятилетия капиталистической эпохи]. О. Р-1. Д.4.

7. ГАПК. Ф.37. [Юго-Камский завод, Свято-Троицкая церковь, метрическая книга за 1784 г.] Оп. 1. Д. 26.

8. ГАПК. Ф. 714. [Материалы по истории Добрянского завода, собранные Е. Туневой (племянницей П.И. Сюзева) и А.А. Володиным (зав. Ильинским районным музеем) по документам, собранным П.И. Сюзевым]. О. 1. Д. 17.

Архивные материалы. Горнозаводской краеведческий музей (ГКМ) им. М.П. Старостина:

9. $\quad$ ГКМ [Киреев В.В. Трудная дорога к храму. 10 с.].

10. ГКМ [Киреев В.В. Имя струй голубых// Край наш Горнозаводский, 1992] оф. 5164.

11. ГКМ [Киреев, Пашийский металлургический завод. Страницы истории. Рукопись] 1991. $61 \mathrm{c.}$

12. Лысьвенский музей. [И.И. Спехов. Очерки по истории Лысьвенского завода]. Инв. 2010. Ф. 2 -в-344. Литература и источники:

13. Адрес-календарь Пермской епархии за 1909 г. - Пермь: Электро-тип. В.А. Чердынцева, 1908. - 321 с.

14. Города-заводы /кол. авторов под ред. Г.Н. Чагина. - Пермь: Книжный мир, 2011. - 584 с. 
15. Добрянке 370. Страницы истории / колл. авторов под ред. М.А. Калинина. - Добрянка: Добрянская типография управления печати и информации администрации Пермской области, $1993 .-70 \mathrm{c}$.

16. Калуиков В.Н., Иванова А.А., Давыдова Ю.А., Фадеева Л.В. Родионов Е.А. - Культурный ландшафт Русского Севера: Пинежье, Поморье / Семинар «Культурный ландшафт»: первый тематический выпуск докладов. - М.: Изд-во ФМБК, 1998. - 136 с.

17. Коровин В.К. Обозрение и описание округа Бесерского завода и Крестовоздвиженских золотых промыслов // Пермские губернские ведомости. - 1862. - № 20, неофициальная часть. - С. 316 - 319.

18. Коровин В.К. Обозрение и описание округа Бесерского завода и Крестовоздвиженских золотых промыслов // Пермские губернские ведомости. - 1862. - № 21, неофициальная часть. - С. 323 - 328.

19. Мамин-Сибиряк Д.Н. Статьи и очерки. - Свердловск: Свердловское областное государственное издательство, 1947. - 408 с.

20. Машкина С.Г. Из воспоминаний жителей поселка Кусье-Александровский // Пятые районные краеведческие киреевские чтения. - Горнозаводск: МУ ЦБС, 2005. - С. 11-17.

21. Металлургические заводы Урала XVII-XX вв. Энциклопедия. - Екатеринбург: Академкнига. $-536 \mathrm{c}$.

22. Отчет Уральской экспедиции для исследования хозяйства казенных горных заводов. Ч. 1. СПб: Типография и литография Л. Бермана и Г. Рабиновича , 1888. - 486 с.

23. Очер - исторический город-завод. - Пермь: ООО «Типография «Астер», 2009. - 146 с.

24. Попов Н.С. Хозяйственное описание Пермской губернии. - Пермь, 1804. - Т. 1. - $401 \mathrm{c}$

25. Чупин Н. Географический и статистический словарь Пермской губернии. - Пермь: Типография Поповой, 1873. - Т. 1. - 577 c.

26. Шадрин Б.Г. История Пермских вотчинных заводов, золотых, платиновых и алмазных приисков, принадлежавших потомкам рода Строгановых - Шаховским, Шуваловым. - Пермь: ПГНИУ, 2014. -122 с.

\title{
THE ORTHODOX LANDSCAPE OF MINING SETTLEMENTS IN THE PERM REGION: A COMPARATIVE ANALYSIS
}

\author{
A.V. Vostroknutov \\ Perm Federal Research Center UB RAS
}

\section{For citation:}

Vostroknutov A.V. The Orthodox Landscape of Mining Settlements in the Perm region: a comparative analysis /I Perm Federal Research Center Journal. - 2021. - № 4. - P. 70-81. https://doi.org/10.7242/2658-705X/2021.4.7

In the article, on the basis of archival, published, and field ethnographic sources, a comparative analysis is undertaken of the Orthodox landscape at 13 mining plants, subdivided into two groups: northern and southern. This division is due not only to geography, but also to the peculiarities of the studied landscape. In the northern group, the sacral space extends from the temple, which forms the center, throughout the plant and further to its mines. This is manifested in the Orthodox names of streets and parts of the plant settlement. In addition to this horizontal spread, there is a vertical one, which is manifested in the fact that the Orthodox names are given to ore layers in some mines. In the group of southern plants, on the other hand, a basic model of the sacral space functioning around the temple is presented. Moreover, three models of the location of temples were identified: central, peripheral with a high-rise dominance and peripheral at the entrance to the plant. All this made it possible to characterize the Orthodox landscapes of different plants, highlighting their similar and distinctive features.

Keywords: Orthodox, church, temple, plant, settlement, cultural landscape, Orthodox landscape, sacral space.

\section{Сведения об авторе}

Вострокнутов Артем Викторович, кандидат исторических наук, научный сотрудник учебнонаучная лаборатории теоретической и прикладной фольклористики, Пермский государственный национальный исследовательский университет (ПГНИУ), 614068, Пермь, ул. Букирева, 15; e-mail: art-vostr@mail.ru 